\title{
THE RELATIONSHIPS BETWEEN THE LITTERFALL AND THE CANOPY CLOSURE OF ULUDAĞ FIR (ABIES NORDMANNIANA (STEV.) SUBSP. BORNMULLERIANA (MATFF.)) FORESTS
}

\author{
DUYAR, A. \\ Department of Forest Engineering, Faculty of Forestry, Karabük University, Karabük, Turkey \\ (e-mail: ahmetduyar@karabuk.edu.tr; phone: +90-370-418-8180; fax: +90-370-418-8181) \\ (Received 20 $0^{\text {th }}$ Nov 2018; accepted $11^{\text {th }}$ Jan 2019)
}

\begin{abstract}
The litter is the organic layer on the forest ground and has a variety of ecological functions. The litterfall is the main source of litter. The structure of forest canopy affects most ecologic processes such as the net primary production and litterfall in forest ecosystems. This research study focused on the exploration of the changes of litterfall based upon canopy closure of Uludağ fir forests. The study area was selected from Bolu Aladağ forests. Ten litterfall traps were systematically emplaced under the stand. The litterfall accumulated in each trap was collected monthly. The hemisphere photographs of the canopy closures above the stands were analysed with Gap Light Analyzer (GLA) software. The canopy closures were calculated separately for each hemisphere photographs with angles expanded in the multiples of $10^{\circ}$ angle of view. The highest correlation coefficient $(\mathrm{r}=0.359)$ was found between the amount of total litterfall $\left(333.5 \mathrm{~g} \cdot \mathrm{m}^{-2} \cdot \mathrm{y}^{-1}\right)$ and the canopy closure at $20^{\circ}$ angle of view. The canopy closure values observed at $20^{\circ}$ angle of view varied between $6.4 \%$ and $83.3 \%$. Different mathematical models were developed to estimate the amount of litterfall fractions based on the canopy closure values at $20^{\circ}$ angle of view. The coefficients of determination $\left(\mathrm{R}^{2}\right)$ for the models developed as part of this study are 0.93 for foliar, 0.82 for seed and 0.83 for wood fraction. Practitioners can estimate the amounts of litterfall components, spreading distances and the accumulating amounts based on the distance by using the mathematical models developed in this study.
\end{abstract}

Keywords: Bolu-Aladağ forests, effective closure, hemisphere photograph, litterfall trap, spreadable litterfall

\section{Introduction}

The litter is the organic layer pooled by the dead plant and animal residues on the forest ground. The litter has variety of ecological functions such as soil protection (Enez et al, 2016), water infiltration (Koralay et al., 2015), nutrient deposits (Dündar, 1988), carbon sequestration (Duyar, 2010) and habitat for soil fauna (Duyar and Makineci, 2016) besides some other indirect ecological functions (Sariyildiz and Savaci, 2017). As stated by Dubber et al. (2017), the amount of litterfall is closely related to the net primary production in forest ecosystems. While the litterfall of deciduous trees is predominantly realized in autumn (Pitman et al., 2010), the litterfall of evergreen coniferous trees befalls through the year (Duyar, 2014).

The structure of forest canopy controls both ecologic and ecophysiological processes. The crown width (Duyar, 2014), self-pruning of branches (Mäkinen and Colin, 1999; Wang et al., 2015), the amount of precipitation on the ground (Kiniş et al., 2011), the amount of snowbank (Duyar and Aydın, 2016), and understory vegetation (McDonald et al., 2015; Chandler and McGraw, 2017) are some of the many examples.

Measurements techniques for canopy closure were studied. Various methods were developed (Mailly, 2017) since 1940s as the effects of canopy closure on stand dynamics were pronounced (Garrison, 1949). The most widely used system of today is the Digital Hemisphere Photograph (DHP) of canopy processed with the computers (Chianucci and Cutini, 2013; Macfarlane et al., 2014; Origo et al., 2017). Numerous 
data such as crown canopy, Woody Area Index (WAI), Leaf Area Index (LAI) and solar radiation penetrating to the stand can be generated with the use of DHP (Liu and Jin, 2017; Mailly, 2017). The litterfall components such as foliar, seed and wood with respect to the stand structure (Liu et al., 2015) and dynamics of decomposition (Zalamea et al., 2012) are estimated based on the established relationships between the canopy data and the ground data obtained from the litterfall collection methods on the ground.

The amount, phenology and the composition (foliar, seed and wood) of litterfall from the trees are under the influence of the mean stand age and height (Atay, 1971), canopy closure (Lopez et al., 2008) and LAI (Liu and Jin, 2017) besides the features of tree species and climate characteristics. The forest practitioners use these data in order to estimate and evaluate the amount, timing and extent of seed cover (Dassot and Collet, 2015) as well as the process of nutrient flow (Magalhães et al, 2014) and carbon sequestration (McGovern and Pasher, 2016) within a stand structure (Leblanc and Fournier, 2017).

Uludağ fir (Abies nordmanniana (Stev.) subsp. bornmuelleriana (Matff.)) is an endemic subspecies of Abies nordmanniana (Stev.) and indigenous to the mountains in the Western Black Sea Region (between Uludağ mount and Kizılırmak river) in Anatolia (Anşin and Özkan, 1997). It occurs at altitudes of 900-2000 m on mountains with the cool and humid weather. Its optimum habitat is about $1550 \mathrm{~m}$ (Kantarc1, 1979). The uneven aged management of fir forests (Sıvacıoglu et al., 2007) create a multiple layered forest structure (Topaçoğlu et al., 2008; Genç et al., 2012) with various sizes of gaps. Fir is a typical shade tolerant tree species (Çalışkan, 1992), and its green crown protrudes up till lower branches (Şevik et al., 2010).

In principle, the litterfall dynamics are critical in the sustainable management of forest ecosystems including the soil properties, nutrient regimes, carbon cycle and some other monitoring studies. Furthermore, litterfall collection method is quite time consuming, exhausting and costly. Developing mathematical models are the most appropriate and an economic method for monitoring studies such as litterfall dynamics and prediction of amount and spreading distances of litterfall components. There are few scientific studies about the dynamics of litterfall in forest ecosystems in Turkey. However, there seems no particular research endeavor designed to investigate the relationships between the amount of litterfall and the canopy closure determined by the DHP in Uludağ fir forest ecosystems. We propose and expect that establishing the relationships between the litterfall collected with the traps and the canopy closure of fir trees determined by the DHP and the exploration of the associated estimation models and methods based on the driven data would contribute to the basic ecological studies in forestry and fill the gaps in the literature as far as fir forest ecosystems are concerned. Thus, the amount and spreading distance of litterfall components will be estimated based on canopy closure ratios in the forest.

This research focuses on the exploration of the changes and the correlation of litterfall in relation to the canopy closure of Uludağ fir forests, determined with the DHP. Based on the results, different mathematical models were investigated for the prediction of the spatial distribution of litterfall, amount of spreadable and collected litterfall. 


\section{Materials and methods}

\section{The study area}

The study was carried out in the Şerif Yüksel Research Forests managed by the Western Black Sea Research Institute in the Aladağ forests located in the southern part of Bolu province in the Western Black Sea Region in Turkey. The research plot lied on a southern aspect with $<5 \%$ slope wand an average elevation of $1570 \mathrm{~m}\left(40^{\circ} 37^{\prime} 12.2^{\prime \prime} \mathrm{N}\right.$ and 31³5'59.5"E) (Fig. 1).
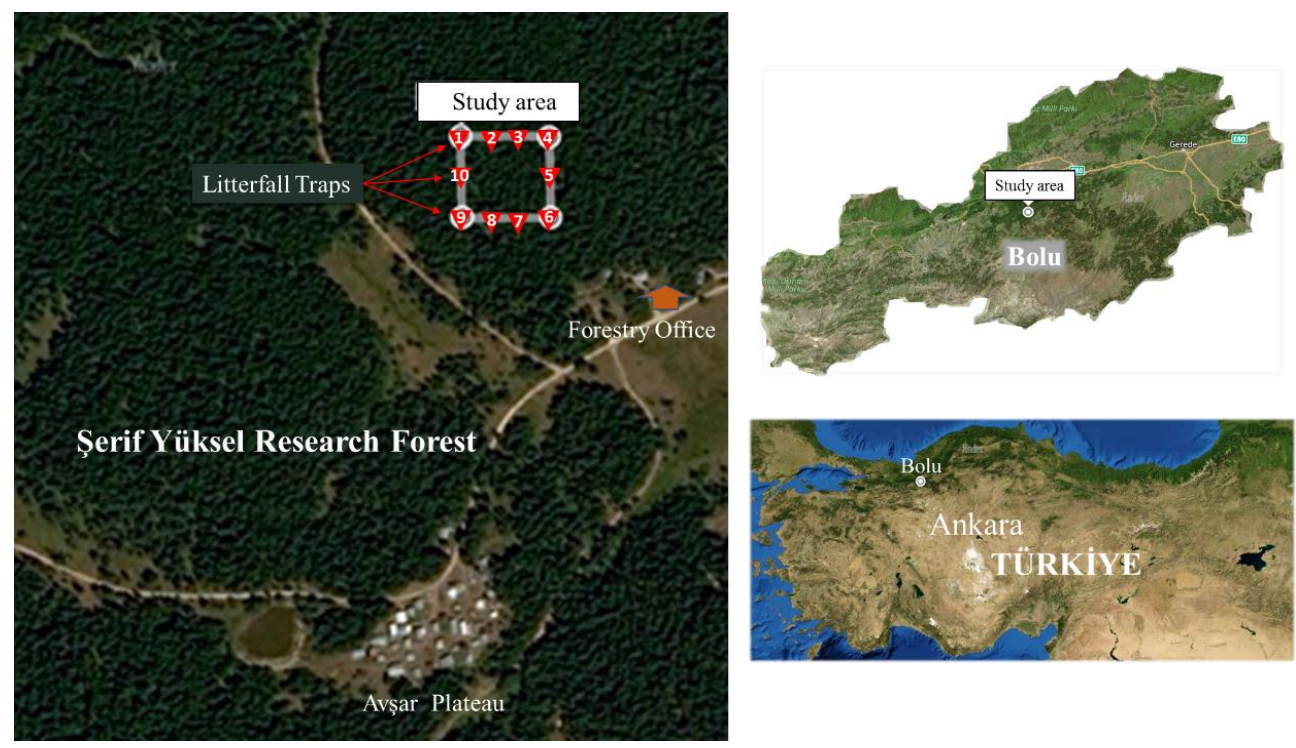

Figure 1. Map of study site and location of plot (Google earth, 2017)

\section{The climate of the area}

According to Thornthwaite climate classification system (Thornthwaite, 1948), based on the calculations using the long-term data (1960-2012) at Bolu meteorological station (742 $\mathrm{m}$ asl), the site had a climate type $\mathrm{A} \mathrm{C}_{2}{ }^{\prime} \mathrm{r} \mathrm{b}^{\prime}{ }_{4}$ at $1600 \mathrm{~m}$ elevation, characterized with (A) a relatively maritime condition, $\left(\mathrm{C}_{2}{ }^{\prime}\right)$ without any water shortages or a small shortage, (r) low temperature and $\left(\mathrm{b}^{\prime}{ }_{4}\right)$ high moisture (Duyar, 2014). This plateau sitting at $1600 \mathrm{~m}$ of elevation is cooler and rainier compared to the city of Bolu (Tolunay, 1997).

\section{Stand characteristics of the area}

The case study area presents multi layered fir stands mixed with relatively few Scots pine (Pinus sylvestris L.) trees and managed by uneven aged management system. All of trees on $20 \mathrm{~m} \times 20 \mathrm{~m}$ area were measured in the middle of study area, for the determination of the stand characteristics of the study area. The average height of the stand was nearly $21.7 \mathrm{~m}$ and the average width or diameter of crown was about $5.1 \mathrm{~m}$ (Table 1).

Table 1. The stand characteristics of the study area

\begin{tabular}{c|c|c|c|c|c}
\hline $\begin{array}{c}\text { The average diameter } \\
\text { at breast height } \mathbf{( c m})\end{array}$ & $\begin{array}{c}\text { Basal area } \\
\left(\mathbf{m}^{2} / \mathbf{h a}\right)\end{array}$ & $\begin{array}{c}\text { Crown } \\
\text { diameter }(\mathbf{m})\end{array}$ & $\begin{array}{c}\text { Average } \\
\text { height } \mathbf{( m )}\end{array}$ & $\begin{array}{c}\text { Dominant } \\
\text { height }(\mathbf{m})\end{array}$ & $\begin{array}{c}\text { Number of trees } \\
(\mathbf{n u m b e r} / \mathbf{h a})\end{array}$ \\
\hline $35.2 \pm 12.5$ & $63.5 \pm 5.0$ & $5.1 \pm 0.9$ & $21.7 \pm 6.4$ & $29.0 \pm 1.9$ & $608 \pm 201$ \\
\hline
\end{tabular}




\section{Litterfall sampling}

The sampling was conducted between 2011 and 2014 years. Ten litterfall traps were systematically emplaced in an interval of $25 \mathrm{~m} \times 50 \mathrm{~m}$ over the one ha of the area (100 $\mathrm{m} \times 100 \mathrm{~m})($ Fig. 1). The litterfall samples were collected once a month by using the 50 $\mathrm{cm}$ depth and $0.25 \mathrm{~m}^{2}(50 \times 50 \mathrm{~cm})$ litterfall traps (ICP Forests, 2004) (Fig. 2). These are located $1.30 \mathrm{~m}$ above the forest floor (Martius et al., 2004). The collected total litterfall (Total ${ }_{L f}$ ) biomass was manually separated into three fraction groups; foliar, seed and wood fraction and oven-dried at $65^{\circ} \mathrm{C}$ for dry weight determination. The foliar fraction consists of the needles of fir in fir forest ecosystems. Seeds refer to the reproductive organs such as flowers, fruits, seeds, catkins and pieces of cones. Wood fractions are woody pieces thinner than $2 \mathrm{~cm}$ in diameter such as twig, branch and bark. It is assumed that branches over $2 \mathrm{~cm}$ in diameter are deadwood, not litterfall fraction (Pitman et al., 2010).
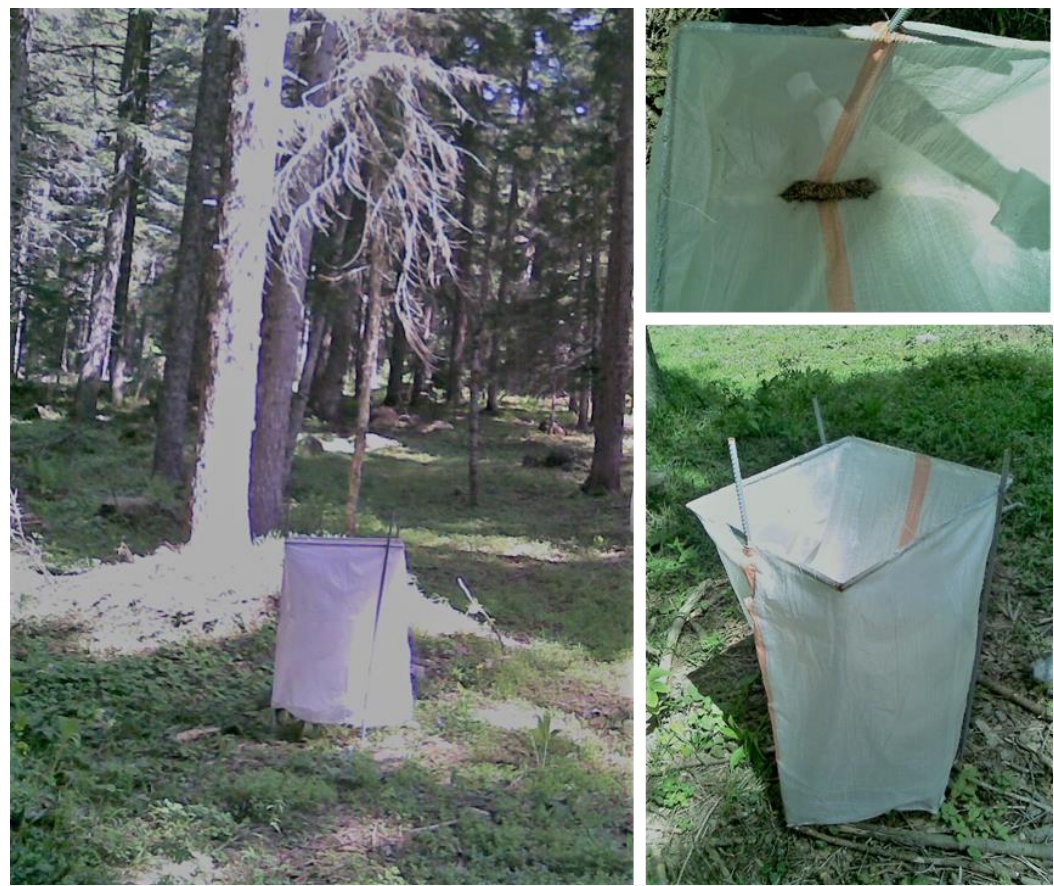

Figure 2. Litterfall traps

\section{Determining canopy closures with digital hemisphere photographs (DHP)}

The canopy DHP over the litterfall traps were taken with a high resolution (12 megapixels) fisheye objective digital camera mounted on the tripod. The default adjustments were selected automatically (Macfarlane et al., 2014). Canopy closures rates were determined with DHP Gap Light Analyzer (GLA) software (Frazer et al., 1999). Each one of the DHP processed with DHP GLA software was sliced into 18 circles with large viewing zenith angles expanded in the multiples of $10^{\circ}$. The largest zenith angle was recorded to be $89^{\circ}$. GLA software computes the percentage of open sky seen (\% canopy openness) based on the angles from the hemispherical photographs (Frazer et al., 1999). Thus, the canopy closure ratio (\% canopy closure) of each circle is separately determined by dividing the closure area by the circle area (Gonsamo et al., 2013). 


\section{Determination of canopy closure areas}

The average stand height is about $21.7 \mathrm{~m}$ (Table 1) and the height at which the traps are located away from the forest floor is $1.3 \mathrm{~m}$. The distance between the trap and the start of the canopy closure (HD) is $20.4 \mathrm{~m}$. The diameters of canopy cover (CD) viewed from the traps were determined with the tangent $(\alpha)$ values of the perpendicular trap centered zenith angles expanded in the multiples of $10^{\circ}(E q .1)$.

$$
\mathrm{CD}=\mathrm{HD} \times \tan (\alpha)
$$

The area of canopy closure viewed from the stated angle was determined with the circle area (A) (Eq. 2).

$$
\mathrm{A}=\mathrm{CD}^{2} \times \pi / 4
$$

The most appropriate correlation was determined at the angle values with the highest correlation based on the angular closure of litterfall components. Then, mathematical models were developed based on the relationships between the amount of litterfall component and the values of canopy closure viewed at the angles above the traps.

\section{Statistical analyses}

The litterfall samples and their components collected monthly from the litterfall traps were evaluated in $\mathrm{g} \cdot \mathrm{m}^{-2}$ unit. The samples were statistically analyzed using IBM SPSS statistics program (SPSS Inc., Chicago, IL, USA). The correlation and the distribution of the samples with respect to the traps and closure are evaluated at $\alpha=0.05$ confidence level. The ANOVA test was used in order to calculate the statistical distribution of samples and Duncan test was used to determine the differences among the samples.

\section{Results}

\section{Distribution of litterfall components}

Mean $333.5(\min =137.8-\max =526.2) \mathrm{g} \cdot \mathrm{m}^{-2} \cdot \mathrm{y}^{-1}$ amount of litterfall was accumulated within 10 litterfall traps with different canopy closures. It was found wide variation among the amount of litterfall collected within the traps due to their locations and variations of canopy closure. The foliar litterfall has the largest share (72\%) of the total amount of litterfall. The rates of seed and wood litterfall were almost similar to each other $(14 \%)$. There were significant differences between the amount of Total Lf, foliar and wood components accumulated within the traps $(\mathrm{P}<0.01)$. The annual amount of collected litterfall components were $2401 \mathrm{~kg} \cdot \mathrm{ha}^{-1} \cdot \mathrm{y}^{-1}$ for foliar, $472 \mathrm{~kg}$ $\mathrm{ha}^{-1} \mathrm{y}^{-1}$ for seed and $462 \mathrm{~kg} \cdot \mathrm{ha}^{-1} \cdot \mathrm{y}^{-1}$ for woody parts (Table 2 ).

\section{Canopy closure}

As seen in the hemisphere photographs, some traps coincided with gap areas under loose canopy closure while others coincided with dense areas under high density canopy of trees. There were also differences in perpendicular canopy closures right over the traps. Additionally, the differences in canopy closures were quite distinct from the center of the traps towards outside. Moreover, the amount of energy and sun light 
penetrating to the crown varies due to the canopy structure of the trees. Such reality influences the size of canopy and the amount of the vegetative and generative organs of the trees. The self-thinning of branches decreased in the trees with plenty of light and located around the large gaps as depicted in Figure 3. The green or live canopy starts at a lower height and cover larger areas.

Table 2. The distribution of litterfall components to the traps

\begin{tabular}{c|c|c|c|c|c|c|c|c}
\hline \multirow{2}{*}{$\begin{array}{c}\text { Litterfall } \\
\text { traps }\end{array}$} & \multicolumn{2}{|c|}{ Foliar } & \multicolumn{2}{c|}{ Seed } & \multicolumn{2}{c|}{ Wood } & \multicolumn{2}{c}{ Total } \\
\cline { 2 - 9 } & Mean & SD & Mean & SD & Mean & SD & Mean & SD \\
\hline 1 & $25.35 \mathrm{bc}$ & 24.62 & 4.81 & 11.69 & $13.70 \mathrm{~b}$ & 34.56 & $43.85 \mathrm{~d}$ & 43.61 \\
2 & $12.00 \mathrm{a}$ & 16.82 & 1.85 & 3.31 & $0.81 \mathrm{a}$ & 1.57 & $14.67 \mathrm{a}$ & 17.35 \\
3 & $25.90 \mathrm{bc}$ & 26.77 & 4.53 & 7.68 & $5.10 \mathrm{a}$ & 7.88 & $35.53 \mathrm{bcd}$ & 30.76 \\
4 & $10.03 \mathrm{a}$ & 12.53 & 1.99 & 5.3 & $0.76 \mathrm{a}$ & 1.78 & $12.78 \mathrm{a}$ & 14.18 \\
5 & $26.47 \mathrm{bc}$ & 30.2 & 4.65 & 9.58 & $2.81 \mathrm{a}$ & 4.79 & $33.93 \mathrm{bcd}$ & 30.16 \\
6 & $26.45 \mathrm{bc}$ & 27.17 & 5.37 & 7.46 & $6.52 \mathrm{a}$ & 13.38 & $38.33 \mathrm{~cd}$ & 34.87 \\
7 & $7.79 \mathrm{a}$ & 8.47 & 2.01 & 4.45 & $1.68 \mathrm{a}$ & 3.9 & $11.48 \mathrm{a}$ & 11.82 \\
8 & $18.41 \mathrm{abc}$ & 18.39 & 4.88 & 12.61 & $1.51 \mathrm{a}$ & 3.58 & $24.79 \mathrm{abc}$ & 21.87 \\
9 & $30.16 \mathrm{c}$ & 30.29 & 6.33 & 15.08 & $3.95 \mathrm{a}$ & 5.66 & $40.44 \mathrm{~d}$ & 34.00 \\
10 & $17.55 \mathrm{ab}$ & 23.32 & 2.9 & 4.7 & $1.66 \mathrm{a}$ & 4.17 & $22.11 \mathrm{ab}$ & 25.32 \\
Total & 20.01 & 23.93 & 3.93 & 9.02 & 3.85 & 12.82 & 27.79 & 30.05 \\
\hline $\mathrm{P}$ & 0.000 & \multicolumn{6}{|c|}{0.330} & \multicolumn{6}{c|}{0.000} & \multicolumn{2}{c}{0.000} \\
\hline
\end{tabular}
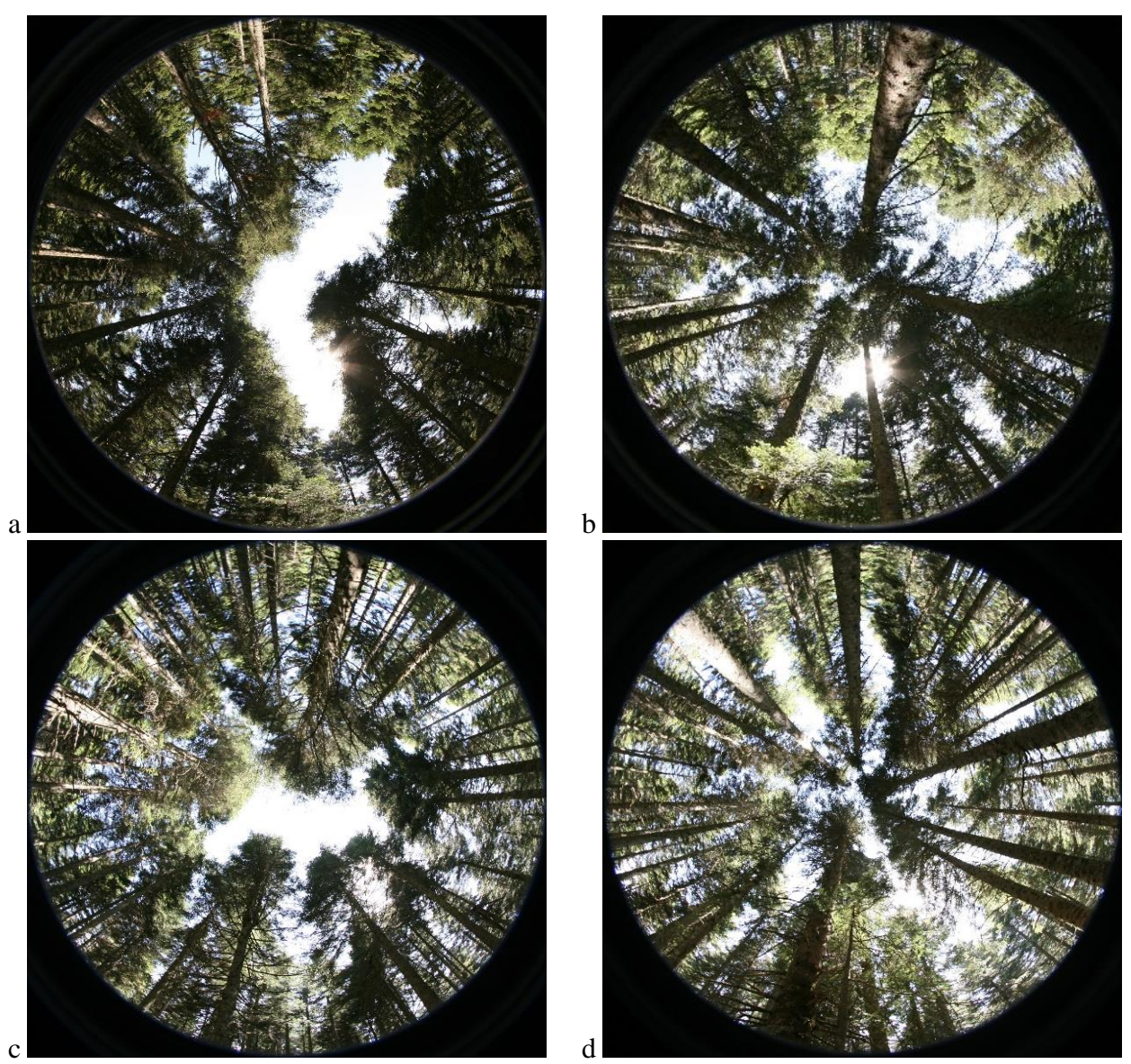

Figure 3. Hemisphere photos of canopy closure (Traps: $a$ 2; $b 3 ; c 8 ; d 9$ ) 
Significant differences were found among the average canopy closure rates of the canopy angularly observed above the litterfall traps $(\mathrm{P}<0.01)$ (Table 3). The crown rates show an increasing trend from the narrow angle of $10^{\circ}(40 \%)$ towards hemisphere $178^{\circ}(81 \%)$. However, certain differences in crown rates in each hemisphere photos enlarging with $10^{\circ}$ zenith angles among the traps were also observed. For example, the average canopy closure $(89 \%)$ at the narrowest angle $\left(10^{\circ}\right)$ was higher than the canopy closure (85\%) at the largest angle $\left(178^{\circ}\right)$ as some traps (trap 6, 3 and 1) coincided with dense canopy closure. The crown rates determined under $10^{\circ}$ zenith angles ranged from $0.13 \%$ to $93.22 \%$ with a Standard Deviation (SD) of $39.82 \%$. Thus, certain differences in the crown rates represented by the traps were also found. The extreme values decreased as the evaluated crown area expanded with respect to the increase of zenith angles. As a result, the crown rates stabilized (mean $=81.4 \%, \mathrm{SD}=4.87 \%$ for $178^{\circ}$ ) (Table 3).

Table 3. The canopy closure rates over the traps by the angles

\begin{tabular}{c|c|c|c|c|c|c|c|c|c|c|c|c}
\hline \multirow{2}{*}{ Angles } & \multicolumn{10}{c}{ Traps canopy closure (\%) } \\
\cline { 2 - 13 } & $\mathbf{1}$ & $\mathbf{2}$ & $\mathbf{3}$ & $\mathbf{4}$ & $\mathbf{5}$ & $\mathbf{6}$ & $\mathbf{7}$ & $\mathbf{8}$ & $\mathbf{9}$ & $\mathbf{1 0}$ & Mean & SD \\
\hline 10 & 84.05 & 0.66 & 88.27 & 2.09 & 47.45 & 93.22 & 0.13 & 18.00 & 64.32 & 1.73 & 39.99 & 39.82 \\
20 & 80.10 & 20.89 & 83.29 & 12.83 & 63.31 & 94.26 & 6.40 & 27.33 & 66.56 & 19.48 & 47.44 & 33.22 \\
30 & 68.55 & 40.38 & 80.41 & 28.79 & 64.37 & 87.47 & 18.12 & 35.38 & 67.08 & 51.22 & 54.18 & 23.02 \\
40 & 66.31 & 51.18 & 75.06 & 42.90 & 61.46 & 80.39 & 31.41 & 46.77 & 68.92 & 63.89 & 58.83 & 15.38 \\
50 & 66.97 & 56.22 & 67.50 & 53.24 & 57.31 & 75.32 & 41.07 & 55.48 & 65.40 & 63.85 & 60.24 & 9.60 \\
60 & 67.03 & 60.09 & 63.98 & 59.26 & 58.02 & 74.70 & 47.80 & 60.84 & 64.19 & 62.49 & 61.84 & 6.87 \\
70 & 66.93 & 63.54 & 64.40 & 62.90 & 58.62 & 76.47 & 54.49 & 63.49 & 64.77 & 63.83 & 63.95 & 5.63 \\
80 & 67.94 & 67.18 & 64.92 & 65.05 & 60.06 & 78.70 & 59.28 & 65.60 & 64.86 & 65.23 & 65.88 & 5.28 \\
90 & 70.27 & 71.05 & 65.44 & 66.80 & 60.46 & 80.01 & 63.34 & 67.34 & 64.99 & 66.47 & 67.62 & 5.33 \\
100 & 72.54 & 74.68 & 66.20 & 69.16 & 61.42 & 81.24 & 65.84 & 68.46 & 65.91 & 68.23 & 69.37 & 5.57 \\
110 & 74.40 & 77.62 & 67.71 & 71.42 & 63.52 & 82.48 & 67.95 & 69.26 & 66.57 & 69.85 & 71.08 & 5.65 \\
120 & 76.17 & 79.57 & 69.47 & 73.36 & 65.43 & 83.95 & 69.43 & 70.32 & 67.89 & 71.69 & 72.73 & 5.67 \\
130 & 77.80 & 81.10 & 71.44 & 75.30 & 67.00 & 85.30 & 71.07 & 71.50 & 69.10 & 73.91 & 74.35 & 5.65 \\
140 & 79.32 & 82.52 & 73.32 & 76.98 & 68.18 & 86.47 & 72.58 & 72.71 & 70.20 & 75.60 & 75.79 & 5.66 \\
150 & 80.70 & 83.64 & 74.81 & 78.53 & 68.99 & 87.27 & 73.88 & 73.87 & 71.06 & 77.23 & 77.00 & 5.67 \\
160 & 82.01 & 84.73 & 76.39 & 79.92 & 70.14 & 87.88 & 75.17 & 75.01 & 72.21 & 78.80 & 78.23 & 5.56 \\
170 & 83.56 & 86.00 & 78.32 & 81.54 & 72.24 & 88.70 & 77.00 & 76.70 & 74.15 & 80.62 & 79.88 & 5.21 \\
178 & 84.87 & 87.12 & 80.01 & 82.98 & 74.30 & 89.56 & 78.73 & 78.39 & 75.90 & 82.15 & 81.40 & 4.87 \\
Mean & 74.97 & 64.90 & 72.83 & 60.17 & 63.46 & 84.08 & 54.10 & 60.91 & 68.00 & 63.13 & 66.65 & 17.96 \\
\hline
\end{tabular}

\section{The relationship between canopy closure and litterfall}

Based on the relationships between the amount of litterfall for each component of litterfall and the values of canopy closure viewed at the angles above the traps, relatively the highest positive correlation $\left(r=0.225^{* *}\right)$ for the woody part was found within the canopy closure at $10^{\circ}$ angle of view. In the meantime, the highest correlations for the foliar component $\left(\mathrm{r}=0.285^{* *}\right)$ and for the seed component $\left(\mathrm{r}=0.136^{* *}\right)$ of litterfall were attained within the canopy closure at $20^{\circ}$ angle of view. 
The levels of correlations show a decreasing trend towards negative values from $30^{\circ}$ angle onwards (Table 4).

The closer the canopy closure of litterfall is to the traps horizontally, the higher the amount of litterfall collected at the traps is. According to the correlation values indicated in Table 4, the amount of litterfall collected in the traps has a limited relationship with the canopy closure viewed at certain angles from the traps. Additionally, Figure 4 shows that canopy closure values observed within the distance from the center towards the areas viewed until $20^{\circ}$ angle of view contribute the highest to the collected litterfall according to the physical and aerodynamic features of litterfall components. However, they indicate decreasing trend after $30^{\circ}$ angle.

Table 4. The relationships of the litterfall fractions at various angles

\begin{tabular}{c|c|c|c|c|c|c|c|c|c|c|c}
\hline \multirow{2}{*}{$\begin{array}{c}\text { Litterfall } \\
\text { fractions }\end{array}$} & \multicolumn{10}{|c}{ Correlations $(\mathbf{N}=\mathbf{3 6 0})$} \\
\cline { 2 - 11 } & $\mathbf{1 0}^{\circ}$ & $\mathbf{2 0}^{\circ}$ & $\mathbf{3 0}^{\circ}$ & $\mathbf{4 0}^{\circ}$ & $\mathbf{6 0}^{\circ}$ & $\mathbf{8 0}^{\circ}$ & $\mathbf{1 0 0}^{\circ}$ & $\mathbf{1 2 0}^{\circ}$ & $\mathbf{1 4 0}^{\circ}$ & $\mathbf{1 6 0}^{\circ}$ & $\mathbf{1 7 8}^{\circ}$ \\
\hline Foliar & $0.273^{* *}$ & $0.285^{* *}$ & $0.284^{* *}$ & $0.274^{* *}$ & $0.214^{* *}$ & 0.101 & -0.00 & -0.03 & -0.04 & -0.06 & -0.06 \\
Seed & $0.135^{*}$ & $0.136^{* *}$ & $0.126^{*}$ & $0.119^{*}$ & $0.104^{*}$ & 0.056 & 0.00 & -0.02 & -0.03 & -0.04 & -0.04 \\
Wood & $0.225^{* *}$ & $0.214^{* *}$ & $0.180^{* *}$ & $0.160^{* *}$ & $0.164^{* *}$ & $0.116^{*}$ & 0.09 & 0.08 & 0.08 & 0.08 & 0.08 \\
Total & $0.354^{* *}$ & $0.359^{* *}$ & $0.341^{* *}$ & $0.322^{* *}$ & $0.272^{* *}$ & $0.146^{* *}$ & 0.03 & 0.00 & -0.01 & -0.02 & -0.02 \\
\hline
\end{tabular}

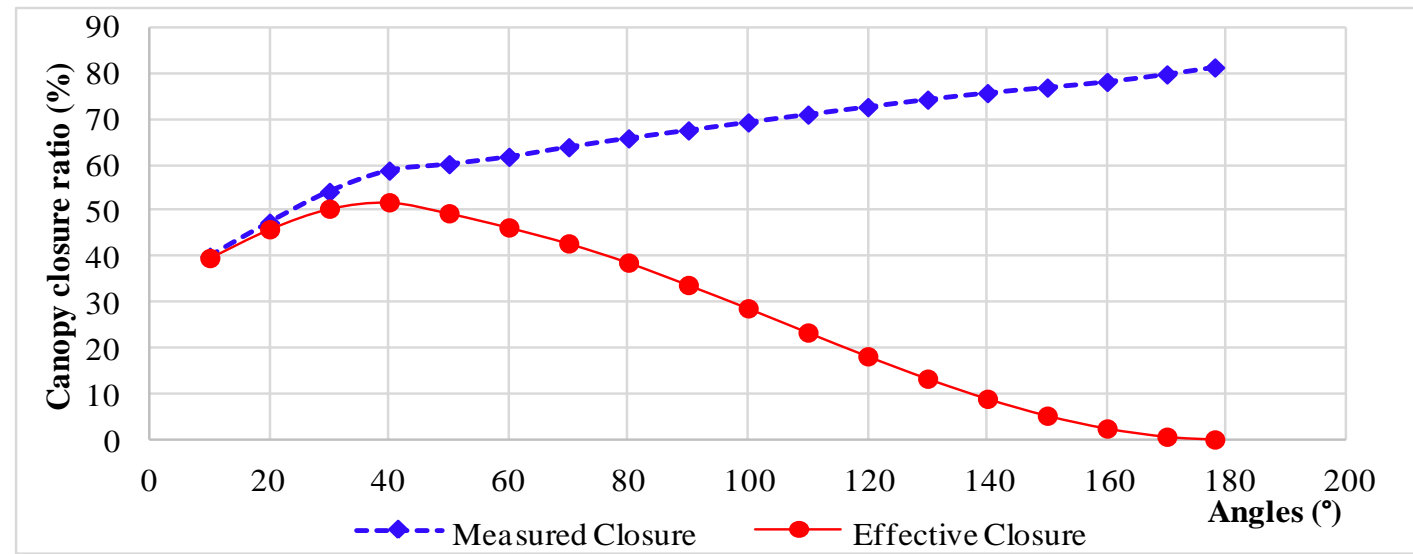

Figure 4. Measured and the effective canopy closure determined by the angles

\section{Effective canopy closure for litterfall}

The diameter and the area of crown viewed at angular side from the traps were determined with the model developed (Eqs. 1 and 2) by the value of zenith angle centered with the traps and the average height of the stand in question (Table 5).

\section{Modeling the litterfall with canopy closure}

The most appropriate correlation is usually determined at the angle values with the highest correlation based on the angular closure of litterfall components. The amount of woody parts of the litterfall at $10^{\circ}$ angular closure is estimated with an exponential function. However, the amount of seed and foliar components as well as the Total $\mathrm{Lf}_{\mathrm{f}}$ at $20^{\circ}$ angular closure are estimated with second degree polynomial functions (Table 6). 
Table 5. The fractions and the effective closure viewed from the angle based on the tree height

\begin{tabular}{c|c|c|c|c|c}
\hline Angle ( $\left.{ }^{\circ}\right)$ & $\begin{array}{c}\text { Viewed } \\
\text { diameter }(\mathbf{m})\end{array}$ & $\begin{array}{c}\text { Viewed area } \\
\left(\mathbf{m}^{2}\right)\end{array}$ & $\begin{array}{c}\text { Measured closure } \\
(\mathbf{\%})\end{array}$ & $\begin{array}{c}\mathbf{C o s}^{\mathbf{2}} \text { adjustment } \\
\text { value }\end{array}$ & $\begin{array}{c}\text { Effective } \\
\text { closure }(\boldsymbol{\%})\end{array}$ \\
\hline 10 & 3.6 & 10.0 & 39.9915 & 0.9924 & 39.688 \\
20 & 7.2 & 40.6 & 47.4432 & 0.9698 & 46.013 \\
30 & 10.9 & 93.9 & 54.1781 & 0.9330 & 50.549 \\
40 & 14.8 & 173.2 & 58.8295 & 0.8830 & 51.948 \\
50 & 19.0 & 284.3 & 60.2363 & 0.8214 & 49.478 \\
60 & 23.6 & 435.8 & 61.8401 & 0.7500 & 46.380 \\
70 & 28.6 & 641.0 & 63.9457 & 0.6710 & 42.908 \\
80 & 34.2 & 920.5 & 65.8828 & 0.5868 & 38.662 \\
90 & 40.8 & 1307.4 & 67.6184 & 0.5000 & 33.809 \\
100 & 48.6 & 1856.9 & 69.3675 & 0.4132 & 28.661 \\
110 & 58.3 & 2666.6 & 71.0778 & 0.3290 & 23.384 \\
120 & 70.7 & 3922.2 & 72.7278 & 0.2500 & 18.182 \\
130 & 87.5 & 6012.6 & 74.3515 & 0.1786 & 13.280 \\
140 & 112.1 & 9869.1 & 75.788 & 0.1170 & 8.866 \\
150 & 152.3 & 18209.8 & 76.9958 & 0.0670 & 5.158 \\
160 & 231.4 & 42050.6 & 78.2253 & 0.0302 & 2.359 \\
170 & 466.3 & 170807.4 & 79.8845 & 0.0076 & 0.607 \\
178 & 2337.4 & 4291086.5 & 81.4013 & 0.0003 & 0.025 \\
\hline
\end{tabular}

Table 6. The mathematical models to estimate the litterfall fractions

\begin{tabular}{c|c|c|c}
\hline $\begin{array}{c}\text { Litterfall } \\
\text { fractions }\end{array}$ & $\begin{array}{c}\text { Angle of effective } \\
\text { closure }\end{array}$ & Mathematical models & $\begin{array}{c}\text { Coefficients of } \\
\text { determination }\left(\mathbf{R}^{2}\right)\end{array}$ \\
\hline Foliar & $20^{\circ}$ & $-0.005 \mathrm{x}^{2}+0.6976 \mathrm{x}+3.1006$ & 0.93 \\
Seed & $20^{\circ}$ & $-0.0011 \mathrm{x}^{2}+0.1422 \mathrm{x}+0.7365$ & 0.82 \\
Wood & $10^{\circ}$ & $1.0997 \times \mathrm{e}^{0.0213 \mathrm{x}}$ & 0.83 \\
Total $_{\mathrm{Lf}}$ & $20^{\circ}$ & $-0.0051 \mathrm{x}^{2}+0.8386 \mathrm{x}+4.7628$ & 0.92 \\
\hline
\end{tabular}

The model representing woody parts shows a convex curve and increases gradually with respect to the increase of $10^{\circ}$ angular closure values. However, the functions of foliar, seed and Total ${ }_{\mathrm{Lf}}$ show a concave curve with respect to the increase in canopy closure values. Thus, the trend of the collected litterfall increases up to a certain point (seed 65\%; foliar 70\%) and decreases right after that point (Fig. 5).

The measured data obtained from the prediction of the spatial distribution of litterfall collected basically from the crown of the trees that are the principle sources of the litterfall were extrapolated. The spatial (horizontal) distribution of litterfall was simulated based on the annual average annually collected litterfall $\left(333.5 \mathrm{~g} \cdot \mathrm{m}^{-2}\right)$ in an area with $3.6 \mathrm{~m}$ in diameter at $20^{\circ}$ angle of view. The horizontal sizes were assumed to be the heights of the trees in order to ease the prediction in practice. The Total Lf estimated with the extrapolation of the theoretical sources of the litterfall was distributed to the horizontal areas according to the tree height (TH) criteria. The horizontal distribution of litterfall decreases with respect to the zenith angles $(\operatorname{Cos} \alpha)^{2}$. 
The Amount of Spreadable Litterfall (ASL) model was able to best represent the relationships $(E q .3)$. It was estimated that the amount of Total $_{\mathrm{Lf}}=13976 \mathrm{~g} \cdot \mathrm{y}^{-1}$ in the litterfall source decreases gradually from the center towards outside further down to the 7-tree heights $(7 \times 20.4 \mathrm{~m}=142.8 \mathrm{~m})$ to $280 \mathrm{~g} \cdot \mathrm{y}^{-1}(2 \%)$.

$$
\mathrm{ASL}=\operatorname{Total}_{\mathrm{Lf}} \times(\operatorname{Cos}(\operatorname{Arctan}(\mathrm{TH})))^{2}
$$

Amount of Accumulative Litterfall (AAL) in a unit area was modelled with an exponential function based on the departure from the center $(E q .4)$. The amount of litterfall to be collected at two-tree distance $(40.8 \mathrm{~m})$ from the litterfall source was estimated to be $0.54 \mathrm{~g} \cdot \mathrm{m}^{-2} \cdot \mathrm{y}^{-1}$ (Table 7).

$$
\mathrm{AAL}=197.47 \mathrm{e}^{-2.129 \mathrm{AB}}
$$

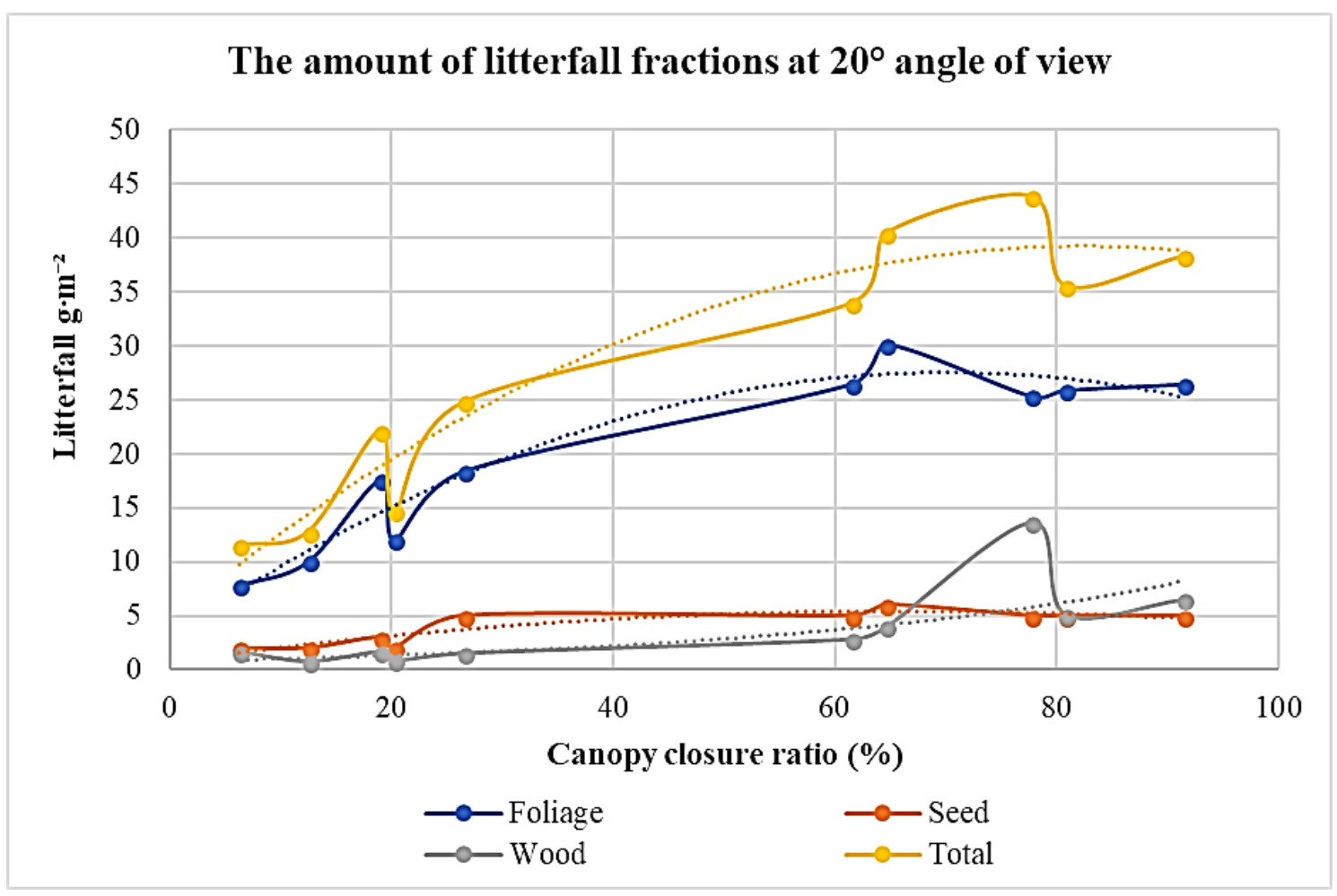

Figure 5. The change of litterfall based on the canopy closure

\section{Discussion}

The average amount of litterfall collected yearly in the traps is about $333.5 \mathrm{~g} \cdot \mathrm{m}^{-2} \cdot \mathrm{y}^{-1}$, $72 \%$ of which is leaves and the rest (28\%) consists equally of seed and woody pats of litterfall fractions. A similar study conducted in China by Yang et al. (1991) in a different Fir stands (Abies fabric) indicated that the amount of litterfall was about 286 $\mathrm{g} \cdot \mathrm{m}^{-2} \cdot \mathrm{y}^{-1}$. The $17 \%$ of the Total $\mathrm{Lf}_{\mathrm{f}}$ was classified for wood fractions, $73 \%$ was for leaves and the rest for the seed fraction. Also, Dündar (1988) found that the amount of litterfall of Scotch pine stands was about $468 \mathrm{~g} \cdot \mathrm{m}^{-2} \cdot \mathrm{y}^{-1}$ in Bolu-Aladağ, in Turkey. Edwards et al. (2017) investigated the proportions of litterfall components and concluded that the rate of foliar is nearly $63.5 \%$, the rate of wood is $27.7 \%$ and the rate of seed is about 
8.8\% in northeastern Australia. While the rates of leaves litterfall fraction are similar in both studies, the rates of seed and woody parts differed from each other. The underlying reasons may be attributed to the fact that the parts of trees would be different as well as the frequency or interval of seed-rich years based on the case study period and the time of the seed maturity would be dissimilar to each other. As the firs are cone rich trees, the parts of the cones assumed to be the part of seed contributed to the litterfall as much wood parts as possible. Kucuk et al. (2014) showed that the average $41 \%$ of canopy litterfall was allotted to the needle, $13 \%$ to the fine branch, $20 \%$ to the medium branch, $18 \%$ to thick branch and $8 \%$ to the very thick branch in young black pine stands.

Table 7. The theoretical distribution of litterfall at the horizontal distances

\begin{tabular}{|c|c|c|c|c|c|}
\hline $\begin{array}{l}\text { Distribution } \\
\text { distance }\end{array}$ & $\begin{array}{c}\text { Distribution } \\
\text { distance for } 20.4 \mathrm{~m} \\
\text { stand height }\end{array}$ & $\begin{array}{l}\text { Amount of } \\
\text { spreadable } \\
\text { litterfall }\end{array}$ & $\begin{array}{l}\text { Ratio of } \\
\text { Totallf }\end{array}$ & Spread area & $\begin{array}{c}\text { Amount of } \\
\text { accumulative litter }\end{array}$ \\
\hline Tree height & $\mathbf{m}$ & $g \cdot y^{-1}$ & $\%$ & $\mathbf{m}^{2}$ & $g \cdot m^{-2} \cdot y^{-1}$ \\
\hline 0 & Source of litterfall & 13965 & 99.9 & 1 & 13962 \\
\hline $1 / 8$ & 2.55 & 13761 & 98.5 & 20 & 674 \\
\hline Quarter & 5.1 & 13154 & 94.1 & 82 & 161 \\
\hline Half & 10.2 & 11181 & 80.0 & 327 & 34 \\
\hline 1 & 20.4 & 6988 & 50.0 & 1307 & 5.345 \\
\hline One and half & 30.6 & 4300 & 30.8 & 2942 & 1.462 \\
\hline 2 & 40.8 & 2795 & 20.0 & 5229 & 0.535 \\
\hline 3 & 61.2 & 1398 & 10.0 & 11766 & 0.119 \\
\hline 4 & 81.6 & 822 & 5.9 & 20918 & 0.039 \\
\hline 5 & 102 & 538 & 3.8 & 32684 & 0.016 \\
\hline 6 & 122.4 & 378 & 2.7 & 47065 & 0.008 \\
\hline 7 & 142.8 & 280 & 2.0 & 64061 & 0.004 \\
\hline 8 & 163.2 & 215 & 1.5 & 83671 & 0.003 \\
\hline
\end{tabular}

The collected litterfall did not show a steady increasing linear trend with respect to the values of canopy closure. The amount of collected litterfall was found to be relatively higher in the stands with loose canopy closures over the traps. Chianucci et al. (2014a) warned that one would incline to make more mistakes in the stands with larger gaps compared to the stands with dense canopy closure. The lower degrees of canopy closure cause the lower layers of the stands to have more sun light energy (Lopez et al., 2008). It is believed that the self-thinning of branches starts and proceed slower, and the amount of accumulated vegetative and generative biomass increase as intense light energy penetrates into the stands. Therefore, more energy penetrates into the stands and the carbon sequestration increases. The amount of light energy penetrating inside the canopy decreases in the high dense stands. As a result, self-thinning process accelerates among the trees and the crowns of the trees develop narrower and start from high above the ground. Thus, volume of the crown of the trees around the gaps are quite bigger and the vegetative and generative organs are plenty in the stands with loose canopy closure as compared to the dense stands. Lopez et al. (2008) indicated that such situation is more important in the forest with mostly deciduous stands and the early plant species within the understory of stands are able to find opportunities to store plenty of light energy before the blooming of leaves in the spring season (before the initiation of 
closure). That the rate of canopy closure is relatively lower in the forests with shade tolerant species like fir influences positively the development of seedlings and the maintenance of the multiple layered and un-even aged stand structure.

The rates of the canopy closure above the litterfall traps show a gradual increasing trend with respect to the increase in zenith angle. The same trend was also observed in some other Pinus, Cupressus, Quercus and Carpinus stands (Gonsamo et al., 2013; Chianucci et al., 2014b). A similar decreasing trend of gaps in canopy closure with respect to the increase in zenith angle was also observed by Gonsamo et al. (2013) and Chianucci et al. (2014b)

In this study, while there were significant differences between the canopy closures above the traps in narrow angles $\left(<40^{\circ}=20^{\circ}\right.$ zenith angle $)$ in our case study, such differences between the canopy closures are gradually eliminated with the expansion of the angles $\left(40^{\circ}<\right)$. Therefore, it becomes difficult to establish a correlation between the canopy closure and litterfall and develop the associated mathematical models when a study is designed to use larger angle. Thus, it is important to decide at the beginning the appropriate angle interval that allows the best relationships with the litterfall collected manually on a certain interval in order to estimate the litterfall based on the canopy closure of stands. The best correlation was found at $20^{\circ}$ angle for foliar and seed and at $10^{\circ}$ angle for woody parts of the litterfall. The canopy closure that indicated the best correlation with the litterfall at $20^{\circ}$ angle was used as a basis in developing the mathematical models in this study. Based on this reality, the mathematical models were thus developed for each fraction of litterfall at these angles. The $\mathrm{R}^{2}$ for the models developed as part of the study are 0.93 for foliar, 0.82 for seed, 0.83 for woody fractions and 0.92 for the Total Lf. Liu and Jin (2016) showed that rate of the relationships $\mathrm{R}^{2}$ between the collected litterfall and the LAI determined by the DHP ranges from 0.42 to 0.76 in coniferous forests in China. As well, they developed models to estimate the seasonal amount of litterfall based on the effective LAI determined at $45-60^{\circ}$ zenith angles.

Although LAI of forest canopy closure could be determined with optical methods, errors may be encountered due to the storage of leaves and trunk's silhouettes on top of each other based on the viewing angles. Similarly, a certain zenith angle needs to be used, instead of a whole area, in determining the values of LAI as an alternative method to estimate the litterfall. The DHPs were analysed at different zenith angles $\left(0-45^{\circ}, 30\right.$ $60^{\circ}, 45-60^{\circ}$ and $0-75^{\circ}$ ) for effective measurements of LAI in deciduous-coniferous mixed forest. The highest correlation was found with the effective LAI viewed at 45$60^{\circ}$ zenith angle based on the litterfall collecting method (Liu et al., 2015). However, errors issuing from the DHP can be removed using appropriate indices (Frazer et al., 2017).

In this study, the effective spreading distance was found to be $7.2 \mathrm{~m}$ diameter viewed at $20^{\circ}$ zenith angle since the parts of the cones were included with the seed fraction of litterfall. Pamay (1962) indicated that the effective seed spreading distance of the seed trees in the edges of stands is 10-40 m for Anatolian pine (Pinus nigra Arnold) and Scotch pine and 20-40 $\mathrm{m}$ for Spruce (Picea sp. Mill.). The spreading distance of the seeds are generally dependent on the height of the trees, the weights and the flying capabilities of the seeds. However, the dry, hot and windy weather conditions help increase the flying distances of the seeds. In the meantime, the flying distance of the seeds can reach up to $400 \mathrm{~m}$ in Anatolian pine, $480 \mathrm{~m}$ for Scotch pine and $200 \mathrm{~m}$ in fir 
trees according to (Atay, 1971). These flying distances include the wing shaped seeds detached from the carpel and cones.

Understanding the litterfall dynamics within the forest ecosystems are critical in the sustainable management of forest ecosystems including the nutrient cycle, carbon sequestration and some other monitoring studies. However, litterfall collection is quite time consuming, laborious and expensive process. One of the most appropriate, practical and economic methods in determining the amount of litterfall and its spreading distances is to develop mathematical models. In this study, we have developed some mathematical models based on canopy closure of the stands using the data obtained from the litterfall collection in Uludağ fir stands. However, the developed models can be rectified with the further data to accommodate various site conditions. Besides, new studies may need to be designed in order to determine the amount and the spreading distances of Total $L$ and its fractions in the gaps of the edges of the stands. The necessary mathematical models can be developed for the other commercial trees in our forest ecosystems based on the sampling method and the models developed in this study.

\section{Conclusions}

In conclusion, this study has developed statistical relationships for estimating canopy cover based on the litterfall in Uludağ fir forest stands. These results obtained in BoluAladağ (Turkey) can also be used for similar ecological conditions of Uludağ fir. The main findings indicated that the highest correlation was found between the amount of Total $_{\text {Lf }}$ and the canopy closure at $20^{\circ}$ angle of view (a circle with the diameter of $1 / 3$ tree height at horizontal) using DHP. The amount of litterfall, spreading distance and the collecting amount based on the distance were estimated by the mathematical models developed as part of this study.

The data of fall and spread of the litter are very important for forestry sciences such as ecology, silviculture and management. Therefore, it would be necessary for similar studies to be carried out for other broad-leaved and coniferous tree species in all forest ecosystems. But, litterfall collection studies are long-term and effortful. Due to these reasons, the planed litterfall researches should be designed appropriate for mathematical modeling in the future. Thus, it may be possible to use the obtained results in wider areas. Practitioners can estimate the amounts of litterfall components, spreading distances and the accumulating amounts by using these mathematical models.

Acknowledgements. This work is supported by the Scientific Research Project Fund of Karabuk University under the project number KBUBAP-17-BM-385.

\section{REFERENCES}

[1] Anşin, R., Özkan, Z. (1997): Abies Mill. firs, seed plants (Spermatophyta), woody taxons. - Karadeniz Technical University, Faculty of Forestry, Trabzon 167: 66-72 (in Turkish).

[2] Atay, İ. (1971): Tabii gençleştirmenin başarılı veya başarısız oluşuna etki yapan en önemli faktörler üzerinde açılamalar. - Journal of the Faculty of Forestry Istanbul 21: 720 (in Turkish). 
[3] Çalışkan, A. (1992): Growth associations and necessary silvicultural processes in Scotch pine (Pinus sylvestris L.) - fir (Abies bornmülleriana Mattf.) - beech (Fagus orientalis Lipsky) mixed stands in Karabük-Büyükdüz research forest. - Journal of the Faculty of Forestry Istanbul 42: 184-209 (in Turkish).

[4] Chandler, J. L., McGraw, J. B. (2017): Demographic stimulation of the obligate understorey herb Panax quinquefolius L. in response to natural forest canopy disturbances. - J Ecol 105(3): 736-749.

[5] Chianucci, F., Cutini, A. (2013): Estimation of canopy properties in deciduous forests with digital hemispherical and cover photography. - Agr Forest Meteorol 168: 130-139.

[6] Chianucci, F., Chiavetta, U., Cutini, A. (2014a): The estimation of canopy attributes from digital cover photography by two different image analysis methods. - iForest 7: 255-259.

[7] Chianucci, F., Cutini, A., Corona, P., Puletti, N. (2014b): Estimation of leaf area index in understory deciduous trees using digital photography. - Agr Forest Meteorol 198: 259264.

[8] Dassot, M., Collet, C. (2015): Manipulating seed availability, plant competition and litter accumulation by soil preparation and canopy opening to ensure regeneration success in temperate low-mountain forest stands. - European Journal of Forest Research 134(2): 247-259.

[9] Dubber, W., Eklundh, L., Lagergren, F. (2017): Comparing field inventory with mechanistic modelling and light-use efficiency modelling based approaches for estimating forest net primary productivity at a regional level. - Boreal Environ Res 22: 337-352.

[10] Dündar, M. (1988): Investigations on the amount of litterfall and the determination of nitrogen given to in the soil by this way in Scotch pine stands, in Aladag-Bolu. - Journal of the Faculty of Forestry Istanbul 38: 106-130 (in Turkish).

[11] Duyar, A. (2010): Carbon Accumulation in Western Black Sea Region Forests. Symposium on Combating Desertification, 17-18 June 2010, Çorum. Proceedings Book pp. 227-234 (in Turkish).

[12] Duyar, A. (2014): Seasonal variations of soil arthropods (Arthropoda) in fir (Abies bornmulleriana Mattf.) ecosystems in Bolu-Aladağ. - PhD, İstanbul University, İstanbul (in Turkish with English summary).

[13] Duyar, A., Aydin, A. (2016): Effects of forest canopy cover on snow accumulation at upper catchments a case from Kartalkaya Turkey. - 1th International Conference on Forestry and Environment: Challenges and Prospects, 20-21 November 2016; Faisalabad, Pakistan, pp. 29.

[14] Duyar, A., Makineci, E. (2016): Seasonal and altitudinal variations of soil arthropods in Abies nordmanniana subsp. bornmulleriana forests. - Bosque 37: 335-345.

[15] Edwards, W., Liddell, M. J., Franks, P., Nichols, C., Laurance, S. G. (2017): Seasonal patterns in rainforest litterfall: detecting endogenous and environmental influences from long-term sampling. - Austral Ecol. DOI: 10.1111/aec.12559.

[16] Enez, K., Sariyildiz, T., Aricak, B., Savaci, G. (2016): Initial litter quality variables and disturbed site characteristics by forest harvesting practices influence litter decomposition rates of Scots pine, Trojan fir and sweet chestnut in northwest of Turkey. - Feb-Fresenius Environmental Bulletin 25(11): 4732-4741.

[17] Frazer, G. W., Canham, C. D., Lertzman, K. P. (1999): Gap Light Analyzer (GLA) Version 2.0: Imaging software to extract canopy structure and gap light transmission indices from true-colour fisheye photographs users manual and program documentation. - Simon Fraser University, Burnaby British Columbia and the Institute of Ecosystem Studies, Millbrook, New York, USA.

[18] Frazer, G. W., Fournier, R. A., Leblanc, S. G., Walter, J. M. N. (2017): View AngleDependent Clumping Indices for Indirect LAI Estimation. - In: Fournier, R., Hall, R. (eds.) Hemispherical Photography in Forest Science: Theory Methods Applications. Managing Forest Ecosystems, Springer, Dordrecht, Netherlands, pp. 153-185. 
[19] Garrison, G. A. (1949): Uses and modifications for "moosehorn" crown closure estimation. - J Forest 47: 733-735.

[20] Genç, M., Kasarc1, E., Kaya, C. (2012): A silvicultural evaluation on the researches of stand structure. - Artvinofd 13: 291-303 (in Turkish).

[21] Gonsamo, A., D'odorico, P., Pellikka, P. (2013): Measuring fractional forest canopy element cover and openness - definitions and methodologies revisited. - Oikos 122: 1283-1291.

[22] ICP Forests (2004): Manual on Methods and Criteria for Harmonized Sampling Assessment Monitoring and Analysis of the Effects of Air Pollution on Forests. Part XI Sampling and Analysis of Litterfall. - United Nations Economic Commission for Europe, Hamburg.

[23] Kantarc1, M. D. (1979): Aladağ Kütlesinin (Bolu) Kuzey Aklanındaki Uludağ Göknarı Ormanlarında Yükselti-İklim Kuşaklarına Göre Bazı Ölü Örtü ve Toprak Özelliklerinin Analitik Olarak Araştırılması. - İstanbul Üniversitesi, Yayın No, 2634, Orman Fakültesi Yayın No, 274, İstanbul (in Turkish).

[24] Kiniş, S., Duyar, A., Aydın, A. (2011): Fir forests and water production. Towards 2023. Nature and Forestry Symposium, 21-27 November 2011; Antalya, Turkey, pp. 409-418 (in Turkish).

[25] Koralay, N., Kezik, U., Kara, Ö. (2015): The possible effects of production activities in the forests on water quality and aquatic ecosystem. - Precision Forestry Symposium at the Production Works, 4-6 June 2015, Çankırı, Turkey, pp. 300-313 (in Turkish).

[26] Kucuk, O., Saglam, B., Bilgili, E. (2007): Canopy fuel characteristics and fuel load in young black pine trees. - Biotechnology \& Biotechnological Equipment 21: 235-240.

[27] Leblanc, S. G., Fournier, R. A. (2017): Measurement of Forest Structure with Hemispherical Photography. - In: Rournier, R. A., Hall, R. J. (eds.) Hemispherical Photography in Forest Science: Theory, Methods, Applications. Springer, Dordrecht, pp. 53-83.

[28] Liu, Z., Jin, G. (2016): Improving accuracy of optical methods in estimating leaf area index through empirical regression models in multiple forest types. - Trees 30: 21012115.

[29] Liu, Z., Jin, G. (2017): Importance of woody materials for seasonal variation in leaf area index from optical methods in a deciduous needleleaf forest. - Scand J Forest Res 32: 726-736.

[30] Liu, Z., Chen, J. M., Jin, G., Qi, Y. (2015): Estimating seasonal variations of leaf area index using litterfall collection and optical methods in four mixed evergreen-deciduous forests. - Agr Forest Meteorol 209: 36-48.

[31] Lopez, O. R., Farris-Lopez, K, Montgomery, R. A., Givnish, T. J. (2008): Leaf phenology in relation to canopy closure in southern Appalachian trees. - Am J Bot 95: 1395-1407.

[32] Macfarlane, C., Ryu, Y., Ogden, G. N., Sonnentag, O. (2014): Digital canopy photography: exposed and in the raw. - Agr Forest Meteorol 197: 244-253.

[33] Magalhães, N. D. S., Marenco, R. A., Camargo, M. A. B. (2014): Do soil fertilization and forest canopy foliage affect the growth and photosynthesis of Amazonian saplings? Scientia Agricola 71(1): 58-65.

[34] Mailly, D. (2017): Hemispherical Photography in Support of Forest Inventory and Silviculture. - In: Fournier, R., Hall, R. (eds.) Hemispherical Photography in Forest Science: Theory Methods Applications. Managing Forest Ecosystems. Springer, Dordrecht, Netherlands, pp. 227-252.

[35] Mäkinen, H., Colin, F. (1999): Predicting the number death and self-pruning of branches in Scots pine. - Can J Forest Res 29: 1225-1236.

[36] Martius, C., Höfer, H., Garcia, M. V., Römbke, J., Hanagarth, W. (2004): Litterfall, litter stocks and decomposition rates in rainforest and agroforestry sites in Central Amazonia. Nutr Cycl Agroecosys 68: 137-154. 
[37] McDonald, S., Dietschler, N., Daly, E. (2015): The effects of canopy gaps on percent cover and species richness of vascular understory vegetation in northern hardwood forests. Cranberry Lake Biological Station 3. - http://digitalcommons.esf.edu/clbs/3.

[38] McGovern, M., Pasher, J. (2016): Canadian urban tree canopy cover and carbon sequestration status and change 1990-2012. - Urban Forestry \& Urban Greening 20: 227232.

[39] Origo, N., Calders, K., Nightingale, J., Disney, M. (2017): Influence of levelling technique on the retrieval of canopy structural parameters from digital hemispherical photography. - Agr Forest Meteorol 237: 143-149.

[40] Pamay, B. (1962): In Turkey, Scots pine (Pinus sylvestris L.) Studies on Natural Rejuvenation Opportunities. - Ministry of Agriculture of the Republic of Turkey, Ankara, publ. no. 337 (in Turkish).

[41] Pitman, R., Bastrup-Birk, A., Breda, N., Rautio, P. (2010): Manual on Methods and Criteria for Harmonized Sampling Assessment Monitoring and Analysis of the Effects of Air Pollution on Forests. Part XIII - Sampling and Analysis of Litterfall. - UNECE ICP Forests Programme Coordinating Centre, Hamburg, Germany.

[42] Sariyildiz, T., Savaci, G. (2017): Environmental controls of litter decomposition dynamics in Turkish forests. - International Symposium on New Horizons in Forestry 1820 October 2017, Isparta -Turkey.

[43] Şevik, H., Yahyaoğlu, Z., Turna, İ. (2010): The effect of different seeding time and seeding conditions on germination in Uludag Fir (Abies nordmanniana Subsp. bornmulleriana Mattf.) seeds. - III. National Black Sea Forestry Congress. 20-22 May 2010; Artvin, Turkey: pp. 780-784 (in Turkish).

[44] Sivacioğlu, A., Ayan, S., Öner, N. (2007): The effects of silvicultural applications on stand structure and enviroment in the Fir stands of Ilgaz Mountains. - Proceedings Book, National Environmental Symposium, 18-21 April 2007, Mersin, Turkey (in Turkish).

[45] Tolunay, D. (1997): Influences of thickening care on the nutrient cycle in the scotch pine (Pinus sylvestris L.) stands in Aladağ, Bolu. - PhD, İstanbul University, İstanbul, Turkey.

[46] Topaçoğlu, O., Bozkuş, F. H., Güney, K. (2008): Silvicultural characteristics of some stand structures in the subalpine and high montane altitudinal zones on the north aspect of Ilgaz Mountain. - Kastorman 8: 1-13 (in Turkish).

[47] Wang, C., Zhao, Z., Hein, S., Zeng, J., Schuler, J., Guo, J., Zeng, J. (2015): Effect of planting density on knot attributes and branch occlusion of Betula alnoides under natural pruning in southern China. - Forests 6(4): 1343-1361.

[48] Yang, L., Wang, G., Yang, Y., Cao, Y., Li, W., Guo, J. (2010): Dynamics of litter fall in Abies fabric mature forest at Gongga Mountain. - Acta Agriculturae Universitatis Jiangxiensis 32(6): 1163-1167.

[49] Zalamea, M., González, G., Gould, W. A. (2012): Comparing Litterfall and Standing Vegetation: Assessing the Footprint of Litterfall Traps. - In: Soneji, J. R., NageswaraRao, M., Sudarshana, P. (eds.) Tropical Forests. InTech, Rijeka, pp. 21-36. 